Article

\title{
Sharing Values for Changing Practices, a Lever for Sustainable Transformation? The Case of Farmers and Processors in Interaction within Localized Cheese Sectors
}

\author{
Morgane Millet * and François Casabianca \\ INRA-LRDE, 20250 Corte, Corsica, France \\ * Correspondence: morgane.millet89@gmail.com
}

Received: 17 June 2019; Accepted: 16 August 2019; Published: 21 August 2019

check for updates

\begin{abstract}
International research and development organizations have acknowledged that localized agrifood systems, particularly geographical indications (GIs), are a lever for evolving towards sustainable agriculture. Such a premise is neither spontaneous nor systematic. Research and development organizations show their limit in proposing approaches to overcome this raised issue: The performance-based approach of sustainability, associated with a strict economical understanding of activities, is at stake. We propose the introduction of a values-based approach to the understanding of localized activities and their contribution to sustainability. We base our demonstration on the study of the relationships between stakeholders within GIs on a day-to-day basis: Corsica and Western Pyrenees (WP) are regions where traditional cheeses (respectively GI Brocciu and GI Ossau-Iraty) are produced with ewe milk. We build a typology of relationships between farmers providing the milk and dairies, based on the theory of worlds of worth (from industrial to artisanal). We cross-reference it with values given to milk and cheese. Despite the framing role of GIs, milk is mainly valued according to industrial criteria of quantity and sound farming practices have no weightage. However, artisanal and civic initiatives have emerged using raw milk and fostering more sustainable practices, notably based on organic farming. Though those initiatives are currently marginal, they might be promising seeds of change.
\end{abstract}

Keywords: geographical indications; milk; terroir; origin-of-food perspective; values; Corsica; Western Pyrenees; France

\section{Introduction}

Environmental and sanitary issues are more and more questioning the way food production is organized and realized nowadays [1]. At various levels, from global policymaking to scientific commissions and local societies, a need of evolution in production, processing, and marketing practices is strongly expressed for enhancing transition towards sustainable food [2,3]. One main issue which remains to be identified is the "seeds of change" [4], that is to say the sources of sustainable transformation that may effectively support such engagements [5]. To address this global issue, the territorial scale is a relevant scale, as more place-based approaches seem able to apprehend the interactions between ecological and social processes and so, to integrate economic, environmental, and social concerns. The localized agrifood systems (LAFSs) are an appropriate framework $[6,7]$ that has been developed to understand and redesign the way local actors are implementing territorial dynamics capable of contributing to sustainability pathways [8]. LAFS are "production and service organizations (units of agricultural production, agrifood enterprises, markets and stores, restaurants, services, etc.) [that are linked] by their characteristics and by their relationship to a specific territory" [9]. 
With such a framework, researchers have particularly taken interest in the origin-of-food perspective $[9,10]$ and studied geographical indications (GIs). Originating from Mediterranean states (France, Italy, etc.), GIs are institutional tools that "legally tie the production to a specific region and codify the particular practices that have defined the production over time" [11]. For a given GI, in a given area of production, local stakeholders collectively build a set of specifications that defines their product and frames the conditions of its production and processing. In doing so, they qualify the link between their product and its origin, or terroir, which can be defined as the material and cultural conditions that have been shaped through time and give uniqueness to the product [11,12]. In Europe, this local collective project is regulated and framed by the European Union (EU) and each member state.

An ideal GI acknowledges the specific quality of a given product, and thus grants it with market differentiation and matching added value; it protects natural and cultural resources that have been developed through time [11], thus fostering a local form of sustainability. This set of idealistic properties has led researchers and development organizations to consider GIs as tools for sustainable development. A guide for promoting sustainable geographical indications was elaborated by the Food and Agriculture Organization of the United Nations (FAO) and research teams [13,14], with the aim of defining how a GI could become more sustainable. The concept of "virtuous circle" is proposed to underline the necessity of renewing the specific resources that have been mobilized for the production process and to ensure a long-term perspective [14]. More generally, those works on GIs have contributed to consideration of the territorial scale as an unquestionable approach to enhance sustainability $[15,16]$ and LAFS as expressions of alternativeness; that is to say, systems that are "signaling a shift away from the industrial and conventional food sector" [17].

However, reality is not as bright, and situations are often more complex. Several studies have identified gaps according to the virtuous circle model [18]. GIs are not only based on artisanal cheese makers who seek to respect ancestral practices. As GIs are powerful market tools, they have attracted a diversity of stakeholders, such as powerful processors and retailors. Therefore, stakeholders might have different interests in taking part in the same GI, leading to the expression of power relations [11,19]. This has consequences on the way economic value is shared among local actors [13,20]. Furthermore, the interaction between GIs and the environment, biodiversity, or the landscape is ambiguous [15,21]. They are associated with traditional production practices, which are considered more natural [22]. However, depending on the level of requirements of production practices that are asked within every GI's specifications [23], and on the actual power relations that exist between stakeholders [11], impact on the ecosystem is variable. In other words, GIs are not systematically tools for sustainability; they are local food systems in which conventional values and alternative ones are competing [17]. As models such as the conventional one has shown stability through time, it also presents its own coherence that legitimizes its dominance for local stakeholders [24]. This could make it hard for small stakeholders to initiate change through collective arenas, such as GIs.

In order to make sure that the changes needed for sustainability transformations are in progress, FAO proposed a large set of indicators to assess sustainable agriculture and food [25]. These indicators, named SAFA for Sustainability Assessment of Food and Agriculture Systems, provide an operational tool able to identify the main problems to be solved. When applied to local agrifood systems, voluntary sustainability standards, eco-labels, codes of conduct, and audit protocols are examined to support the decision-making processes within the systems. Such an approach to sustainability is mainly turned towards the performance of the system according to a holistic and a generic view of what should be a sustainable system. Though a territorial scale was pointed out to be pertinent, the 'performance' approach fails to tackle the specificity of each local food system in enhancing sustainability transformations [26]: From one system to another, diverse stakeholders and groups or categories are included, or not, into the decision-making processes. This impacts the way the various ecological and social concerns are taken into consideration. Balancing such a performance-based approach with a values-based approach might be more appropriate to identify to what extent changes 
are meaningful for the local actors [4,5]. Following Miller [27], it becomes crucial to address the incommensurable polarity between value as price and values as not reducible to monetary evaluation.

The cheese sector appears to be particularly relevant from which to explore this orientation as the supply chains are generally comprised of (i) an upstream portion made of several farmers producing raw material (milk) and (ii) a downstream portion made of a few cheese makers processing this raw material and distributing the final product (cheese). Farmers and processors need to agree on the milk's pricing. Most studies focus on the asymmetry between the seller and the buyer and demonstrate the existence of power relationships [28,29]. However, other items are negotiated as well, in particular, the farmers' production practices and to what extent the milk fits the processor's expectations [30]. Considering local food systems (whether they are under GI or not), farmers and processors also negotiate on elements that might impact the sustainability of their chain, as well as the product's links with local culture, biodiversity, or the ecosystem $[4,11,15,30]$. Thus, relationships between local stakeholders are not limited to pricing; they are fed by values-based contents, which have to be identified and understood.

This leads us to postulate in this paper that between farmers and processors, normative elements circulate through products' transaction and that they might represent an interesting perspective, regarding choices in farming practices and their consequences on local sustainability. Sharing values, beyond pricing and the economic dimension, remains for now a blind spot of research, whereas it might be a relevant approach needed to identify seeds of change for the adoption of more sustainable practices. Our hypothesis asserts that looking at the pattern of shared values in the relationships between processors and farmers in a given localized agrifood system is a way to progress in such an approach: Values given to both the initial raw material and the final product may represent a significant component of that relation. As we focus on such objects, we anchor our work in the theory of "worlds of worth" [31]. In order to justify their actions, people anchor them in a "world" that presents its own coherence according to given principles and predominant values (or worth): A domestic world is based on honesty, a merchant one on richness, an industrial one on efficiency, and a civic one on equity. The plurality of possible worlds implies that actors find compromises in order to achieve collective actions. Such a theory has shown interesting results concerning sustainable agriculture models: It permitted the role of those principles to be demonstrated in the conception of agricultural models and discussion of the multiple transition pathways opened by the combinations of models [32].

We base our empirical work on dairy-ewe production in Corsica and the Western Pyrenees (WP) (France). Both of these local agrifood systems are known to produce traditional cheeses, involving different categories of stakeholders: On-farm producers and refiners on the one hand, dairy-ewe farmers and dairies on the other hand. Those systems have been developed with the official acknowledgment and construction of a GI, GI Brocciu since 1983 in Corsica and GI Ossau-Iraty since 1980 in WP. In such systems where cheese is to be linked to its origin, what importance is given to milk in the production process? How is it translated in dairies' expectations regarding farmers' practices? We first describe our case study and methodology. Considering our questions, we need to tackle diversity under different aspects: The diversity of firms and the diversity of milk suppliers at a global level but also the diversity of milk suppliers within each firm. With our qualitative inquiry, we were able to elaborate a typology of relations based upon the worlds of worth. We crossed it with the values given to milk and cheese by both farmers and dairies, so that we could determine to what extent those types of relations might be related to given choices of farming practices. We finally discuss to what extent those results might go beyond the world of cheeses under GI and embrace a more general feature for supporting sustainability transformations. 


\section{Materials and Methods}

\subsection{Contexts of Dairy-Ewe Production within the Western Pyrenees and Corsica}

In the Western Pyrenees (WP), 14,000 tons of cheese are produced, 30\% of which is GI Ossau-Iraty, a pressed non-cooked cheese. In Corsica, 2500 tons of cheese are produced, 20\% of which is GI Brocciu, a fresh cheese made from a mixture of cooked whey and milk [33]. Diverse stakeholders are involved in the local dairy sector. First, 7 dairies in WP and 18 in Corsica make local cheese. They collect milk from numerous dairy-ewe farmers: Reaching 267 farms in Corsica in 2014 and 1460 in WP. Second, on-farm production is strong within each system, representing $30 \%$ of local cheese production and 250 additional producers who make cheese from their herd's milk in Corsica, 15\% of it and about 400 additional producers in WP. Both Corsica and WP are traditional regions of pastoralism [34]. This type of animal husbandry used to be based on specific production practices, such as free-range grazing in Corsica, and summer transhumance in Corsica and WP. Such practices were efficient as adapted animals have been bred through times. Consequently, dairy production used to be seasonal, when grass was abundant, from the end of winter to the beginning of summer.

Seasonality remains nowadays. Most of the dairies do not collect milk all year long. They "close" during the traditional unproductive season of dairy-ewe production, that is to say during the end of summer and the beginning of autumn. Furthermore, this traditional breeding system has been partially translated into both GIs' sets of specifications (Table 1). Most local farmers adhere to those GIs, thus complying with their respective specifications [34]. As far as Corsican dairy-ewe farmers are concerned, they are all affiliated to GI Brocciu, through their dairy. In total, $90 \%$ of dairy-ewe farmers are affiliated to GI Ossau-Iraty in WP; the other 10\% of farmers do not comply with the GI's set of specifications, they use a foreign breed, the 'Lacaune Breed', which is associated with the productivist farming model (unseasoned dairy production, indoor breeding, etc.).

Table 1. Main specifications regarding farming practices in GI Brocciu and GI Ossau-Iraty *.

\begin{tabular}{|c|c|c|}
\hline Specifications & GI Brocciu & GI Ossau-Iraty \\
\hline Authorized breeds of sheep & Corsican Ewe & $\begin{array}{c}\text { Pyrenean breeds } \\
\text { (Manech and Basco-Béarnaise) }\end{array}$ \\
\hline Season of production & & $\begin{array}{l}\text { Between November 1st of year Y-1 and August 31st of year Y. } \\
\text { Milking cannot go further than } 265 \text { days/year }\end{array}$ \\
\hline Pastures' management & & $\begin{array}{l}\text { Organic manure comes from Ossau-Iraty's area of } \\
\text { production. It is limited to 50T/ha/an. Mineral fertilization is } \\
\text { limited as well. }\end{array}$ \\
\hline \multirow{3}{*}{ Feeding } & \multirow{3}{*}{$\begin{array}{l}\text { Feeding must be bused on } \\
\text { rangelands and grazing. } \\
\text { Complementation with fodder } \\
\text { and concentrates is authorized. }\end{array}$} & $\begin{array}{c}\text { Their daily diet is composed of grazing and dry fodder (such } \\
\text { as hay). It cannot exceed } 1 \mathrm{~kg} \text { DM **. Ewes have to graze at } \\
\text { least } 240 \text { days/year. }\end{array}$ \\
\hline & & $800 \mathrm{~g}$ DM of concentrates maximum in the daily ration. \\
\hline & & $\begin{array}{l}\text { GMOs are forbidden. } \\
\text { Full ration and Fermented fodder are forbidden (by 2018). }\end{array}$ \\
\hline Autonomy & $\begin{array}{l}\text { Fodder and concentrates can come } \\
\text { from outside of the Brocciu's area, } \\
\text { if it represents less than } 20 \% \text { of } \\
\text { the complementation. }\end{array}$ & $\begin{array}{l}\text { Buying animal food (fodder and concentrates) outside of the } \\
\text { Ossau-Iraty's area is limited. }\end{array}$ \\
\hline Level of production & & 300 liters/dairy ewes/year \\
\hline
\end{tabular}

In both GIs, thermic treatment of milk is authorized.

In Corsica, since the last modification of GI Brocciu's set of specifications (1998), the use of pastoral lands has been central for dairy production and farmers must respect a minimal threshold for their farms' self-sufficiency concerning animal feeding. However, since the 2000s, dairies have publicly expressed that they chronically lack local milk, leading them to increasingly buy foreign milk to produce local cheeses (except for Brocciu, which has to be produced with Corsican milk): Two million 
liters were imported in 2012, while 6 million liters of local milk were delivered to Corsican dairies [34]. In such a context, there have been local concerns about the extent to which dairies and farmers respect the Brocciu's set of specifications.

In WP, since 2006, the Ossau-Iraty's set of specifications has been reinforced; requirements about breeding practices aim to regulate the process of intensification that has been occurring there and which has been identified as a threat to traditional practices and the local sustainability of agriculture [34]. This change in the specifications is coherent with the observed tendency of French GIs' mountain cheeses to develop more environment-friendly practices [15]. In those cases, environment-friendly practices mostly deal with the feeding of animals: "Using only direct grazing and hay is associated with the use of natural resource specific to mountain areas, maintenance of grassland and pastures, preservation of their biodiversity and, consequently, maintenance of an open landscape" [15] (in this article, we will not develop how such stances (actual impact of those different specifications on the environment) might be controversial [32,35]). A group of Pyrenean farmers has highlighted that those new expectations are too high considering the current payment of milk and that they might not comply with them and quit the GI Ossau-Iraty by 2018.

GI Brocciu and GI Ossau-Iraty frame local production practices and processes of cheese respectively in Corsica and in WP. However, they do not prevent local controversy. Moreover, they authorize a significant diversity concerning production practices as well as milk's management and processing.

\subsection{Legal Frame for Ewe Milk's Pricing}

Another set of regulations frames dairy-ewe production. Under the EU's regulation for free and competitive markets, price fixing has to be specific to each firm and milk prices cannot be negotiated among collective institutions, such as associations for the defense and management of GIs. Still, as a national legal obligation, the pricing of milk has been dependent on its quality (bacterial quality and physicochemical composition) since 1969 in France. Therefore, dairies and farmers of each local sector have to agree on the criteria according to which milk is paid. Those "local inter branch agreements" were signed in 1990 in WP and in 1999 in Corsica. Since then, milk prices have been adjusted depending on the richness (fat and protein) and bacterial quality (coliform bacteria and butyric spores are markers of the milk's hygienic quality). In WP, since a more recent collective agreement, somatic cells have been also scored, as they are an indication of the health state of dairy-ewes (presence of mastitis). Furthermore, in WP, since 2006, dairies and farmers have all agreed to differentiate the price of milk produced under GI Ossau-Iraty's set of specifications from the price of milk produced under no requirement: It has to be minimum of $60 €$ more (for $1000 \mathrm{~L}$ ).

Under GI Ossau-Iraty's specifications, standard milk is paid around $1080 € / 1000 \mathrm{~L}$ in WP; after applying quality criteria, the average paid to producers was $1020 € / 1000 \mathrm{~L}$ in 2013 (data published during the annual reunion of the local inter-branch association in October 2014). Concerning Corsica, under GI Brocciu's specifications, milk was paid $1240 € / 1000 \mathrm{~L}$ in 2013 (data published with the annual report of the local inter-branch association in 2014). Quality of data is not as precise in Corsica as in WP. Hence, we were not able to access the prices of standard milk. Those average prices are higher than the other French dairy-ewe basins (structured by the GI Roquefort Cheese), where milk was paid $890 € / 1000 \mathrm{~L}$ in 2013 , or even other European countries, such as Italy or Spain, where milk was paid $800 € / 1000 \mathrm{~L}$ in 2013 [33]. Furthermore, the average milk price has been increasing since the beginning of the 2000s in Corsica and WP, but the increase has not been enough to compensate the increase of production costs (purchase of herd feed, fuel, fertilizer, etc.).

Beyond these common local rules, such as pricing according to quality criteria or a bonus for producing under GI Ossau-Iraty's requirements, every dairy and its matching group of dairy-ewe producers have their own practices concerning milk pricing and its differentiations. 


\subsection{Approach and Methodology}

As it has been explored concerning GI Beaufort [30], diversity that is observed in milk's management and processing can be linked to the way milk quality is defined, which depends on how cheese quality is defined inside each dairy. Therefore, it influences the dairy's expectations about milk; it shapes the relationship between the dairy and its farmers. In other words, when studying the relationship between farmers and dairies, we need to pay attention to how milk and cheese are considered and qualified. This lays on measurable items, such as milk's pricing, but also on given practices (technical elements and logistics, such as milk's collection, sampling, and control of its quality) and incommensurable values $[27,30]$. We can obtain this type of information through qualitative research, based on semi-structured interviews and discourse analysis [36]: We need to interview dairies and producers about their relationship and all that it carries with it (perceptions about milk and cheese). With such an approach, when we build our sample, we seek for the expression of diversity: Diversity of dairies, diversity of farmers, and livestock farming systems.

Concerning the dairies, we built our sample based on the diversity of the firms (legal status, size of the firm) and according to their commercial strategy (what type of products are sold, proportion of GI cheeses). Six dairies were met in WP, 7 in Corsica. The processing of cheese actually brings diverse stakeholders together: Farmers produce milk that is regularly collected by milk carriers; milk is brought to a dairy unit where it is analyzed in order to prevent any sanitary issues. If there are any problems, a technical agent can intervene at the farm level. Milk is then processed into cheese under the cheesemaker's responsibility; cheese is finally sold according to the strategy developed by the dairy's manager. We preferably met the dairy's manager and the technical agent of each dairy.

Interviews were about the evolution of the dairy (notably production strategy, commercial strategy) and their relationships with their dairy farmers. We asked the dairies' managers to characterize farmers according to their production practices and the nature of their relationships; potential tensions or conflicts were to be explained, how the milk's price is built, what the expectations on milk qualities are, and how they impact the price. At the end of each interview, we asked the dairies' managers to identify a sample of farmers that we could meet, according to given criteria: The diversity of the relationships (close, indifferent, conflictual) and diversity of farming systems (intensive, traditional, organic, etc.). This methodology is based on the premise that, in most cases, the dairy managers and technical agents and their suppliers have known each other for a long time; moreover, the dairy's managers and technical agents have an idea of their farmers as a whole (area of milk's collection) and of the diversity of livestock farming systems [30].

This methodology permitted us to include farmers that would have not been identified and contacted otherwise (through classical channels of information). We met 28 farmers in WP, and 20 farmers in Corsica. They are distributed among the different dairies that were interviewed previously (Table 2). Interviews were about the farm's trajectory and how farming practices evolved through time and about the nature of relationships with the farmer's dairy and the other farmers (of the dairy, or not). We also asked them about what a good local cheese and good local milk ("from here") are, and to express their point of view about the cheeses that are made with their own milk.

Interviews were conducted in 2014 and 2015 [37]. Each interviewee's discourse was then stripped off according to the different themes. Those matching grids constituted our basic material for analysis. 
Table 2. The interviewed dairies: main characteristics and matching interviewed producers.

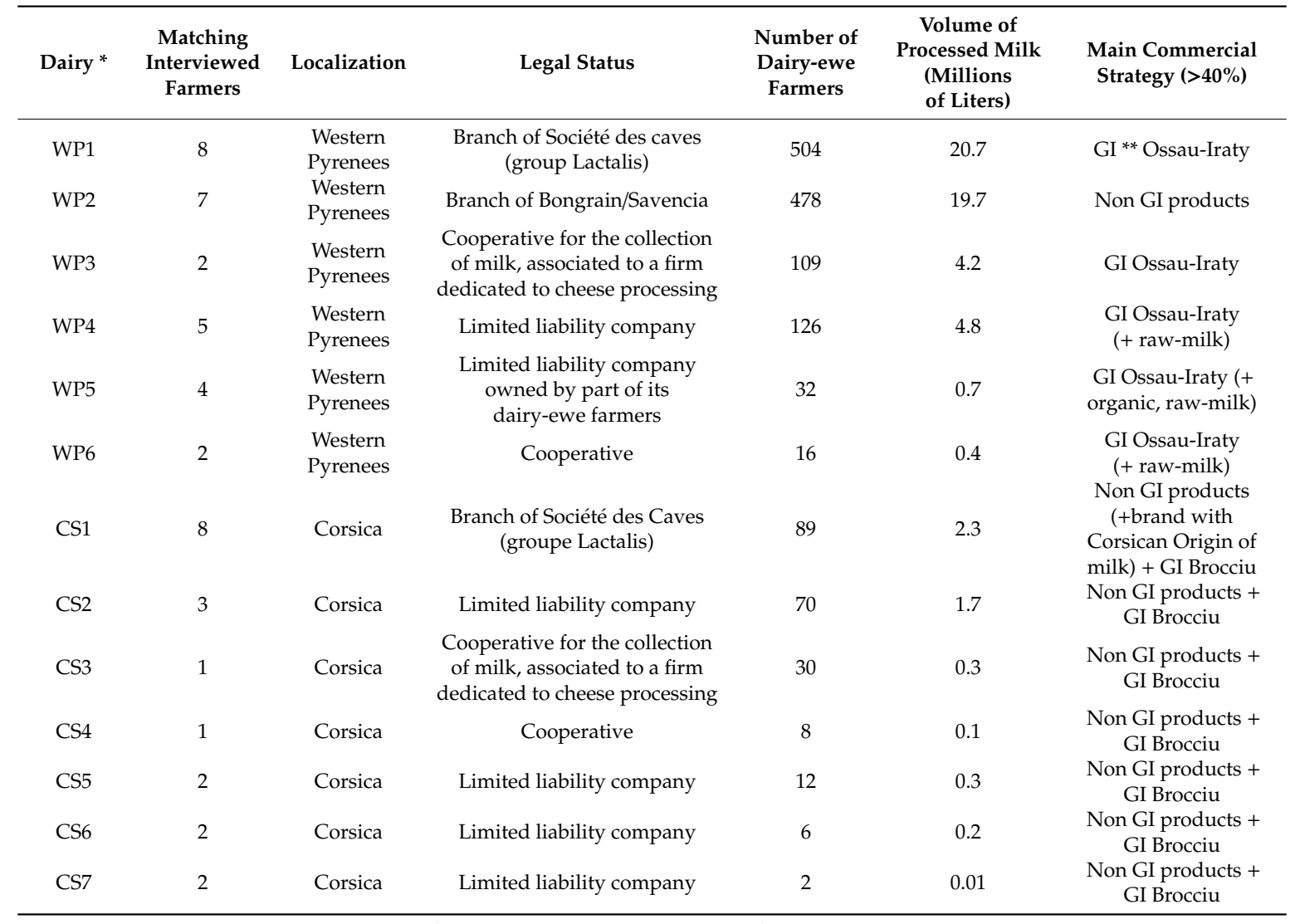

${ }^{*}$ In order to respect anonymity of our interviewees, the name of each dairy that we met has been translated into a code, that associates its localization (WP for West Pyrenees, CS for Corsica) and a number. ${ }^{* *}$ GI for Geographical Indication.

\section{Results}

\subsection{A Diversity of Dairies and Farmers}

Our dairies' sample shows diversity, concerning legal status and size (number of dairy-ewe suppliers, volume of processed milk) (Table 2).

Commercial strategies are diverse, and they might lead to various expectations about milk quality. Most of the dairies produce GI cheese but with different levels of importance. In WP, some dairies (WP5, WP6) mainly base their production process on GI Ossau-Iraty, and they do not accept farmers that do not adhere to the GI. The other dairies are more oriented towards a brand strategy: They mainly valorize their own products, which can be under GI Ossau-Iraty (WP1, WP4) or not (WP2). In Corsica, CS1 have a special brand, which guaranties that cheeses are made with Corsican milk (in a context of under production, and frequent foreign supply).

In complementarity with an origin-of-food strategy, some dairies (WP5, WP6, CS6, CS7) preferably use raw-milk. One of them (WP5) combines the use of raw milk with the organic label. In WP, when dairies developed a special range of raw-milk cheese, they develop a set of requirements concerning production practices that are more demanding than the GI specifications, in order to guarantee milk quality. Targeted practices are the exclusive use of dry fodder (before it becomes compulsory with the GI Ossau-Iraty in 2018) or the affiliation to the organic label.

WP2 has developed a different strategy, through specific contracts with farmers that do not adhere to the GI: In those, farmers engage themselves to comply with complementary requirements on the traceability of dairy production, mostly based on the maintenance of the milking equipment. 
Concerning our farmers sample, due to our method (established list by each dairy), we met heterogeneous numbers of producers per dairy, but we acceded to diverse forms of relationships between farmers and each dairy: Farmers who are shareholders of their dairy, farmers who are local leaders and have specific interactions with the dairy's managers, farmers who have family relationships with the dairy's managers, and farmers who do not share such characteristic and "just" deliver their milk to the dairy. We also acceded to diverse livestock farming systems, of different sizes (herds, surfaces) and different production choices (use of spontaneous resources, cultivation of grass, use of local breed). They are located in different geographical regions, from plains and hillsides to mountains. More specifically in WP, we interviewed producers that are engaged in specific lines of production, like raw-milk production (6/28) or organic production (1/28), but also non-GI production (4/28).

\subsection{A Diversity of Relationship Models}

With the data extracted from our interviews, we are able to understand how farmers and dairy managers interact, through milk pricing and management, and how each of them perceives their relationships. Therefore, we are able to systematize the diversity that lies in the relationships between dairies and farmers and to propose a typology of relationships (Table 3).

Table 3. Typology of relationships between dairies and dairy-ewe producers in Corsica and Western Pyrenees.

\begin{tabular}{|c|c|c|c|c|c|}
\hline Type & Civic & Artisanal & Paternalistic & Industrial & Merchant \\
\hline $\begin{array}{l}\text { Matching dairy } \\
\text { (and farmers) }{ }^{*}\end{array}$ & $\begin{array}{l}\text { WP5 (1), } \\
\text { WP6 (2) }\end{array}$ & $\begin{array}{l}\text { CS4, CS6, CS7 } \\
\text { WP5 (3) }\end{array}$ & $\begin{array}{l}\text { CS2, CS3, CS5 } \\
\text { WP4 (5) }\end{array}$ & $\begin{array}{c}\text { CS1 } \\
\text { WP1, WP3, WP4 } \\
\text { WP2 (5) }\end{array}$ & WP2 (2) \\
\hline $\begin{array}{l}\text { Structure of } \\
\text { the firm }\end{array}$ & $\begin{array}{l}\text { Cooperative or } \\
\text { Limited liability } \\
\text { company owned } \\
\text { by farmers }\end{array}$ & $\begin{array}{l}\text { Familial firm - } \\
\text { Limited } \\
\text { liability company }\end{array}$ & $\begin{array}{l}\text { Familial firm - Limited } \\
\text { liability company or } \\
\text { cooperative associated } \\
\text { to an enterprise for } \\
\text { cheese processing }\end{array}$ & $\begin{array}{l}\text { Branch or cooperative } \\
\text { associated to an } \\
\text { enterprise for cheese } \\
\text { processing }\end{array}$ & Branch \\
\hline $\begin{array}{c}\text { Size of } \\
\text { milk's collect }\end{array}$ & $10-30$ farmers & Less than 10 farmers & 15-100 farmers & 80-500 farmers & $\begin{array}{l}\text { About } 100 \\
\text { farmers }\end{array}$ \\
\hline Milks' pricing & $\begin{array}{l}\text { Collective } \\
\text { negotiation }\end{array}$ & $\begin{array}{l}\text { Individual } \\
\text { negotiation }\end{array}$ & $\begin{array}{l}\text { (collective negotiation - } \\
\text { farmers' leaders) }\end{array}$ & $\begin{array}{l}\text { collective negotiation - } \\
\text { farmers' leaders }\end{array}$ & $\begin{array}{c}\text { Contract - } \\
\text { farmers' } \\
\text { leaders }\end{array}$ \\
\hline Correspondent & $\begin{array}{c}\text { Shareholder } \\
\text { farmers + } \\
\text { dairy's manager }\end{array}$ & $\begin{array}{l}\text { Cheesemaker/dairy's } \\
\text { manager }\end{array}$ & $\begin{array}{l}\text { Technical agent }+ \\
\text { group of farmers }\end{array}$ & $\begin{array}{l}\text { Technical agent }+ \\
\text { group of farmers }\end{array}$ & Technical agent \\
\hline $\begin{array}{l}\text { Level of } \\
\text { requirement on } \\
\text { milk's quality }\end{array}$ & $\begin{array}{l}\text { High }(\text { raw-milk })- \\
\text { specific } \\
\text { requirement }\end{array}$ & l & $\begin{array}{l}\text { Low (inter-branch } \\
\text { basis) - possible } \\
\text { arrangements }\end{array}$ & $\begin{array}{l}\text { Low (inter-branch } \\
\text { basis) }\end{array}$ & $\begin{array}{l}\text { High - specific } \\
\text { requirement }\end{array}$ \\
\hline $\begin{array}{l}\text { How farmers } \\
\text { and dairy's } \\
\text { managers } \\
\text { characterize } \\
\text { their relation }\end{array}$ & $\begin{array}{l}\text { The dairy is an } \\
\text { extension of } \\
\text { the farm }\end{array}$ & $\begin{array}{l}\text { Inter-knowledge and } \\
\text { long-standing } \\
\text { contact. Partnership. }\end{array}$ & $\begin{array}{l}\text { Compromise between } \\
\text { inter-knowledge and } \\
\text { industrial management }\end{array}$ & $\begin{array}{l}\text { Corporate culture. } \\
\text { Industrial } \\
\text { management. }\end{array}$ & $\begin{array}{l}\text { Commercial } \\
\text { partnership. }\end{array}$ \\
\hline
\end{tabular}

* As the relationship is characterized by both dairy's managers and farmers, different types of relationships can coexist within the same dairy.

When interviewed farmers are part of an "industrial" type of relationships, they are involved in a formalized relationship where exchanges with the dairy are taken in charge by an association of elected breeders. At least once a year, the dairy's manager and the elected breeders meet in order to negotiate the milk's price and the pricing criteria based on the milk's quality. Farmers that are part of the "industrial" type of relationship characterize their dairy as a professional structure that has proven to be serious (payment, technical support). This appreciation embraces the farmers' union too: Leaders have proven to be serious, especially in price's negotiation. In those situations, roles and competences are well defined and circumscribed. As a farmer expresses it, "we do try to produce good milk. It is their role to make good cheeses. We are not going to explain to them how to make good cheeses." 
Expectations about milk are limited to the local inter-branch's agreements. There is a technical agent who is in charge of monitoring the milk's quality.

Concerning farmers who deliver their milk to WP2 but do not adhere to GI Ossau-Iraty, another type of relationship has been built through years: The "merchant" one. It is similar to the industrial one on several aspects, but the relationship between producers and the dairy is described otherwise. There is a part of collective negotiation as those farmers are represented by elected ones who negotiate with the dairy in order to frame individual contracts. However, farmers eventually stand on a peer-to-peer interaction and the content of each contract is personalized. In that case, farmers consider the dairy as a client or a partner. One of them declares: "to me, it's a client. A client who is listening, with whom I have a good relation, but still, it is a client. He has its expectations as well as I have mine." Requirements about milk are more demanding, especially concerning industrial expectations (traceability, regularity of production).

On the contrary, concerning the "artisanal" type, interviewed farmers describe their relationships with dairies on a more personal, domestic point of view. In most cases, they have known each other for a long time. This type of relationship concerns several Corsican dairies. All of those Corsican dairy managers used to be farmers (CS6, CS7) or still are (CS4), which contributes to a common sense of belonging. Such a type of relationship is also observed concerning WP5 and farmers that are not shareholders of the dairy. Interviewed farmers and the dairy managers deal with long-term relationships and mutual trust. As the manager explains, "there are no obligation to collect them, but they don't have to sell us their milk either. They are free, except that it has been years and years that we have worked together, a historic relationship based on trust has settled between us." The dairy's small size is associated with informality, in contrast with industrial relationships, where the relationship between farmers and the dairy manager is codified, notably through the existence of a strong farmers' association. Expectations about milk are not really formalized either, although cheesemakers generally work with raw milk: There are no collective negotiations or collective agreements.

Between those two opposites, some interviewees describe their relationship using "paternalistic" vocabulary. Dairy managers insist on the fact that their firm is a local family business, passed on from one generation to next, and that farmers are part of this family; farmers insist on the domestic nature of their relationships. However, farmers do remind us that between producers and dairy managers, each one has his or her own role to play too: As one of the Corsican farmers expressed it, "bosses will be bosses".

Finally, for farmers who are shareholders of their dairy (WP5, WP6), the dairy can be seen as an extension of their farm, a tool vowed to serve producers' interests. As one of the WP6's producers puts it, "from mere producers who sold our milk to an industrial dairy and waited for our paycheck, we took interest in our final product, in what was processed in the factory." In that case to be considered as a "civic" type, they share a collective project about valorizing local milk and local cheese; expectations about milk are high and coherent with the local farming model that they have built. In WP6, farmers are also involved into the day-to-day business: They weekly give two half-days each to participate in the functioning of the dairy (cheese processing, refinement, milk's collection, etc.).

\subsection{Introducing Values Given to Cheese and Milk}

In Corsica, for some dairies' managers (CS2, CS3, CS5, CS6), Corsican cheese is linked to know-how in cheese process. Little attention is paid to the milk's provenance, between Corsica and foreign localities (French mainland, Sardinia). Furthermore, for most of them (except CS6), a possible difference between those two types of milk is erased with the milk's thermic treatment. In our interviews, such a practice is justified by the fact that Corsican milk is said to be dirty: High bacterial levels are persistent, concerning some farmers, and as dairies need local milk, they do not feel like sanctioning them nearly enough to drastically change hygiene practices (to suspend milk collection for instance, which can be practiced in WP). Concerning the interviewed farmers who deliver milk to those dairies, they have a quantitative and financial representation of milk: Volume and bacterial levels matter, as they impact 
payment. Moreover, they declare that they do not recognize themselves in the final product, as their milk is an insignificant portion of it, mixed with foreign milk. To them, Corsican cheese cannot be made from another milk than the Corsican one.

Such a point of view is shared by all interviewed farmers and by two dairy managers (CS4, CS7). Those artisanal cheese makers only work with local milk, they collect limited volumes and they work with raw milk. Such a structural organization, and the matching practices, lead their delivery farmers to feel closer to them because they seem to share similarities with on-farm cheese making, which is considered to be the most authentic way to produce local cheese.

None of those relationships directly lead to specific sets of practices.

The case of CS1, an industrial dairy, however, is particularly worth highlighting. The dairy's manager, the technical agent, and the leader of the farmers' union share a common vision of the local dairy-ewe sector. To them, Corsican cheese is to be made, preferably, with local milk; foreign milk is supplied because they currently do not have a choice. Therefore, their lecture of the local context is a reason to advocate for intensifying production practices, and to be proactive about it. In that case, besides a quantitative perception of milk, there is a strong attachment to local development. This value is shared by the dairy's employees as well the interviewed CS1 farmers. It is doubled with the farmers' pride concerning one of the dairy's cheese: They do not find it authentic, but it is destined to foreign markets and it is considered to be a commercial success.

Concerning WP, difference is based on the provenance (between local and foreign) as well for those who do not adhere to the GI Ossau-Iraty (mostly WP2 and non-GI farmers). For the others, difference is mainly based on a specific production practice, farming with local breeds (under GI's specifications) or with foreign ones (outside of the GI Ossau-Iraty's requirements). Such distinction is based on the shared assumption that every farmer who produces milk with the local breed respects traditional production practices, even though some farmers have intensified their farming system [38]. This type of differentiation is inclusive and authorizes local diversity in farming practices: Small farms and big farms coexist; traditional farms and intensive ones coexist as well. In most cases, dairies' employees and farmers consider milk as a commodity, which is evaluated through its sanitary quality and its richness. Such a pricing mechanism does not acknowledge that there are different ways to produce local milk either, more or less intensified. This is also a means to delegitimize efforts that are done with the GI's specifications (or beyond them): Several stakeholders observe that GI milk and non-GI milk often share the same properties according to that quality criteria; as a farmer delivering milk to WP1 expresses it, "what looks like milk more than milk?"

In that case, it is interesting to observe the paradox most farmers deal with. To them, the cheeses produced with their milk are not typical, they are standard and industrial. However, they are reminded each time that those cheeses are commercial successes, and that such products comply with distant consumers' demand: According to a farmer supplying WP2, "they do know how to make good cheese, at least, the one that they can sell or want to sell. As long as we are not compelled to eat it, I don't really care. As long as they pay us for our milk!" Such a situation is reinforced by the fact that the dairies' most popular cheeses are usually non-GI ones; they do not deal with constraints in production or processing. However, such cheeses are far from farmers' own ideal of a typical local product, which, in most cases, would be made by shepherds in summer pastures. In this ideal representation, milk is produced with one herd, it is not pasteurized, and, therefore, it expresses the terroir; that is to say, the pastures' quality (varieties of plants, sun's exposition). The more farmers are productivist, the more they refer to this traditional way of producing, arguing that it is rare and that not everyone could produce this way. In doing so, they justify their own conception of livestock farming, which is standardized and aligned with their dairy's conception of milk (quantity and universal criteria of quality).

Another association between local milk and local cheese was identified. It concerns farmers and dairy managers involved in the "civic" type of relationship as well as farmers and dairy managers involved in the "artisanal" type of relationships and adhering to a special line of production (raw milk, 
organic production) (WP4, WP5). Working with raw milk is declared to be an art where the cheese makers try to make microflora express itself. One manager synthetizes the philosophy with those terms: "Pasteurization breaks milk's value. It cancels the milk's flaws. So, if I pasteurized, what would be my interest in paying higher for the milk?" This appreciation of milk impacts the way it is managed and processed. While in WP, milk collection is mainly organized according to logistical parameters, like the proximity of farmers or their storage capacity of milk. Whatever their farming practices are, dairies managers working with raw milk have developed a specific collection concerning raw-milk suppliers. Furthermore, as quality must be impeccable, dairy managers (WP4 and WP5) pasteurize milk that is produced in the beginning (December) and at the end of the producing season (June and July), when it might be too dirty. Such practices boost the status of raw milk compared to other milks.

In those cases, farmers feel responsible for what they produce. One of the WP6's farmers says "we had to learn how to make milk again. ( ... ) With the previous dairy [an industrial one], if your level of butyric was too high, they sanctioned you with 10ct and that was all. From now on, if you bring milk which is not good, you know that it will impact the dairy. We involve ourselves, and our associate farmers." More generally, farmers are proud of their milk. In most cases, they are proud of their dairy's cheese too: It is typical and it is close to on-farm cheese. Cheese based on raw milk appears to be a suitable compromise for them. Furthermore, cheese is presented as a synthesis of a combined work (giving value to production practices, to milk) and to a shared agricultural model. A farmer who adheres to the organic label and sells his milk to WP5 expresses most reasons why he adheres to his dairy's vision: "I feel a lot of affinities with WP5's orientations. They are working with the GI Ossau-Iraty. There are incentives in the milk's pricing. We are involved in the final product too."

Therefore, if we integrate new objects, such as milk and cheese, into our typology (Figure 1), a continuum appears and permits us to identify potential levers for more sustainable practices.

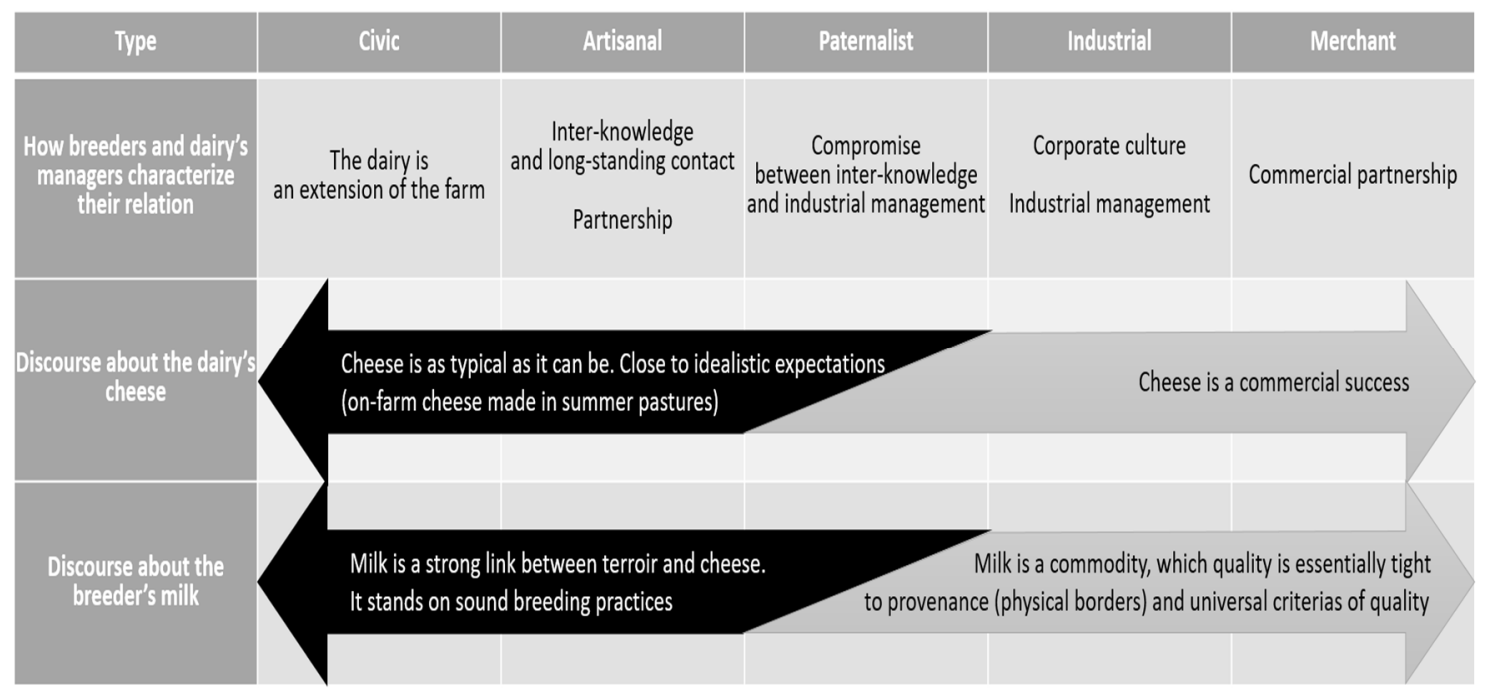

Figure 1. Enriched typology of relationships between dairies and farmers in Corsica and Western Pyrenees (WP).

\subsection{Consequences on Farming Practices}

In most cases (middle of our continuum: Artisanal, paternalistic, and industrial—Figure 1), little is currently done by dairies' managers and technical agents in order to directly influence farmers' breeding practices. Along with farmers, they consider that regulation through local collective agreements has been enough to frame farmers' practices. To them, they can and they must act at this collective level. Such behaviors are not likely to explicitly influence farming practices, whether they are ecofriendly or not.

However, some situations can be associated with a more proactive behavior favoring given practices. In one extreme (left of our continuum: Civic and artisanal-Figure 1), dairy managers 
(WP4, WP5, and WP6) and interviewed farmers (7) have agreed on the necessity to work on the quality of their cheese and its link to terroir. This has material consequences as the milk's price is higher than the conventional one (from 25 to $245 €$ in supplement per $1000 \mathrm{~L}$, depending on the dairies and the requirements). Additionally, the expectations on the milk's bacterial quality are higher, but they are better rewarded than standard pricing. Some of the farmers involved in this model were already applying those practices: They did not use fermented forage (2) or they were converting to organic agriculture (1); when they were able to valorize such choices through a local outlet, it clinched their decision. The other interviewed farmers declared that they decided to adapt their farming system to comply with those requirements. Requirements about farming practices can go further: The shareholders of the cooperative WP6 are willing to apply a threshold of production for each farm. If they produce more, the milk's price decreases due to a volume excess. According to the dairy's manager, this measure is an expression of the shareholders' set of principles: Preserving small local farms with a satisfying income, thus limiting concentration and intensification. Nonetheless, as the cooperative's creation was quite recent (2005) and the activity is currently stabilizing, this measure has not been applied yet.

On the other extreme (right of the continuum, industrial and merchant-Figure 1), dairy managers (WP2, CS1) develop specific and strong incentives to adapt production practices to classical industrial principles [5], that is to say optimal adequacy between production and industrial need, and regularity of production along the year. Concerning WP2, in their individual contracts, each farmer declares what they will produce along the period of production. They engage themselves to stick to this estimate: If they do so, they get a bonus, otherwise they might be financially sanctioned (depending on the dairy's current needs in milk). Contracts comfort farmers in a set of intensive practices, such as farming with foreign breeds, indoor farming, etc., even though they are not socially accepted locally; the practices that are accepted are prescribed with the GI Ossau-Iraty. This firm applies such a model with the few farmers that are outside of the GI, but managers are also trying to apply it to their other local suppliers, who adhere to the GI. Even though elected breeders have resisted to such strategy, they had to compromise, and the regularity of production is currently applied to them as well. It is translated into a seasonal pricing of milk. One of the five interviewed farmers, who also comply with GI's expectations, declared that such an incentive has worked for him.

In Corsica as well, a dairy that deals with the industrial model (CS1) has developed specific and strong incentives in order to boost local production. Such a case leads us to insist on the local context, that is to say underproduction in Corsica: The dairy pushes farmers to work on their herds' productivity and, associated with the union's leaders, they work on intensifying production practices. This relies on financial incentives, such as a production bonus-if a farmer produces more than the average of the three previous production campaigns, then his or her excess milk is paid a higher price-or a technical bonus-if farmers agree to work on the genetic breeding of their herd (by adhering to the genetic selection program of the local breed), they receive a bonus. Furthermore, CS1 pushes its suppliers to unseasoned their production: The dairy is willing to pay extra for milk when it is produced early in the season (from 20 October to 15 November). All farmers are not receptive to such a system, but some did change their farming practices. When interviewed, the CS1 technical agent declared that about $40 \%$ of their delivering farmers were actually receptive to their multiple incentives. Among the seven farmers that we interviewed, a farmer clearly shares the agent's vision: He is the leader of the farmers' union and he participated to the conception of those incentives. Three others stated that they were influenced by the dairy, as the technical agent helped them conceive their "livestock farming project", that is to say a set of changes in the farm. Those ones mostly deal with animal feeding, from the decrease of outdoor feeding (pasture and free-range grazing) to the purchase of specific food supplements, and genetics.

\section{Discussion}

Our case study constituted a trial for the virtuous circle of origin-linked quality conceived by the Food and Agriculture Organization (FAO) [13]. We aligned with previous studies according to which 
GIs might not always be strong enough to implement local social equity and environmentally accepted practices [11]. Focusing on the relationships between dairies and farmers, we gave more attention to milk and cheese, and how they are judged and traded within each local agrifood system, so we could understand how it might be a vector for more sustainable practices. We finally acknowledge that such a phenomenon is quite marginal in our cases, although increasing [39], leading us to consider them as possible seeds of change [4].

\subsection{From Collective Action to Individual Incentives: Different Levels for Fostering Transformation}

"The specifications represent a crucial tool in ensuring a pay-back effect for farmers and producers by outlining their roles in providing the unique natural and human resources; they thus can bind the GI value chain to primary producers, who therefore have a say in negotiating price and more generally in managing the GI" [13]. In our cases, it appears that the role of primary producers in the cheeses' specifications have been acknowledged, at least concerning WP. In Ossau-Iraty's case, the recent changes in the GI's specifications contributed to strengthening its link to terroir, and to integrate more explicitly sustainable practices [34].

However, our focus on relationships between dairies and farmers led us to understand that the coherence between specifications of production practices and value given to milk and cheese is at stake within both GIs. In both cases, even though requirements about production practices might be considered as high, they are not actually translated into the final product. In other words, the GI's specifications seem to give power to farmers, but the actual behavior of farmers and dairies weaken their position: Quality is predominantly considered according to industrial criteria and measurable properties. Similar conclusions were drawn concerning Manchego cheese, a Spanish cheese made from (pasteurized) ewe milk [13]: The milk's price appears to be higher than non-GI milk. However, the value of the milk dedicated to GI Manchego is not linked to the GI's requirements or to the cheese's value, which is less valorized than the other Spanish cheeses. It is linked to the local industry's needs and to an expanding market. In parallel, recent changes in the specifications authorized food supplementation for the dairy ewes, thus intensification. With this recent weakening of the GI's specifications comes uncertainty regarding the sector's long-term sustainability.

Such observations can be extended to other types of products, such as tequila, which followed the same path as Manchego cheese [11]. In her study, Bowen identifies that the industrial conception of quality predominates within GI Tequila, which is coherent with the processors' strategies. To her, this behavior is different from farmers' perception of tequila's quality which is far more complex and linked to terroir. Through our own case studies, we demonstrated that such a dichotomy is not systematic: Processors and farmers take active (and diverse) roles in building their relationships and qualifying their product [40], and farmers can share the same vision of quality as processors, leading to a more complex network where farmers are divided. Such a situation might impede the potential reaching of a consensus-driven perception of quality among producers, and weaken their bargaining power within collective institutions, such as the ones that manage GIs.

\subsection{Values Given to Milk and Cheese, Important Factors of the Equation}

Value given to milk and cheese permitted us to identify three main tendencies.

First, industrial and merchant models are associated with a commercial representation of cheese. Milk is considered as a commodity: Its perceived quality is not tied to its terroir (how it is made in this specific place) but to provenance (it was made in this place) [41,42]. Industrial cheese making is associated with "standardized ingredients" [43], which can be reached through measurable criteria of quality (richness, sanitary level) and thermic treatment. Through those expectations, diversity of milks and their richness are denied as they are all evaluated according to universal criteria, such as quantity and biochemical levels. As we observed in our cases, those models might willingly push farmers to change their farming practices; it essentially leads to intensification. Such a posture comforts a common justification based on the need to "feed the world" [32]. 
Still, dairies do not always have a proactive behavior concerning farmers' change of practices. In that case, their absence of involvement reveals how poor their expectations about dairy production are (link to terroir, hygiene). Such a stance is translated into a weak differentiation of the milk's price, which apparently allows a large panel of practices but favors livestock farming systems that can produce the most with the least costs (performance). In such a context, dairy farms have known concentration and intensification. Therefore, the apparent absence of direct action can be as revealing as its presence.

In the other extreme, civic and artisanal models of relations are associated with cheese being considered as close to idealistic expectations as it can be. In that case, milk is considered to be a strong link between terroir and cheese. Basing her understanding of artisanal cheese making on professional book guides, Paxson characterizes it as the following: "Guided by sensory analysis, artisan cheese makers adjust their methods to work with rather than against seasonal and climatic variations in milk that affect fermentation and coagulation as well as the color and flavor of cheese" [43]. From this point of view, cheese presents a certain diversity that depends on the cheese maker, but also on the season when milk is produced. Such diversity can be seen by local stakeholders as an expression of their terroir, as in the Comte case [44].

Such a perception of milk and cheese stands on the research of sound farming practices. This is especially the case of the civic model, where local stakeholders, dairy managers, and producers are willing to implement a specific agricultural model that would respect the link to terroir and the environment. Such a stance is blurrier in the case of the artisanal model: The domestic nature of the relationship between dairies' managers and farmers lays on the assumption that farmers still practice traditional livestock farming systems that appear to be more sustainable [22], but there are no guarantees that they currently do so. Still, these models might be the most likely to foster sustainable local practices. This goes beyond the respect of environmental principles to endorse a social dimension through the respect of farmers' work. Therefore, terroir can be a source of power for farmers if all the stakeholders acknowledge that (i) they are responsible for the link between a given area and the final product, through livestock farming, more specially local feeding; and (ii) there is a recognized influence of it on the taste of the final product (notably through its diversity) [11]. Such a remarkable phenomenon was observable concerning Comte cheese [11,44], where a consensus has emerged regarding the predominant role of farmers in preserving local resources and enhancing a typical taste.

In the middle, paternalistic models are a more fluid category, dairies' managers can borrow from both the industrial model and the artisanal one. Their direct influence on farmers' livestock farming systems appears to be weak. However, their territorial embeddedness might be a lever for change: If they were to consider milk and cheese according to civic standards, their local identity and recognition might be a strong argument for farmers to follow such transition. This was observed with WP4 who developed a special line of production based on raw milk and was successfully followed by local farmers. On the contrary, if they were to actively push farmers to intensify their production practices, a part of their suppliers might follow them for the same reason. For instance, one of the Corsican dairies (CS2) has started adopting similar incentives as CS1. Consequently, paternalistic dairies' managers are a significant category of stakeholders that we have to consider. The question for development organizations might still be how to push those stakeholders towards fostering sustainable practices.

\subsection{Identifying Seeds of Change}

Finally, along with the general conscience that agroecological transition stands on the evolution of values and networks $[4,32,35]$, we postulate for a significant change in how local milks and cheeses are considered by dairies and farmers. More than the specific case of GIs, cheese sectors, such as the ones that we studied, have the advantage of presenting a tangible object that every stakeholder can appropriate: Cheese. This same object can condensate values that go beyond its commercial worth and therefore convey expectations about farming practices, through a GI's specifications or 
not $[27,43]$. This could generate solidarities and alliances between local stakeholders; in our case, this was noticeable between dairies and farmers, but new relations with on-farm cheese makers could be expected too and explored. In that sense, cheese can be a medium for change and it might catalyze a transition towards sustainable agriculture.

Similar results were found concerning two cases of mountain cheese production [15]: Specific production practices are associated with specific qualities of the final product; even though arguments are essentially focused on the link to origin, there is currently an emerging discourse on the positive impact of such processes on the environment. This goes beyond the old continent where terroir has shown its interest; work on artisanal cheese making in the United States shares common results [43]: Those cheesemakers do not refer to terroir from the point of view of tradition but from the point of view of adaptation. They seek to develop a holistic approach of their farm and to adapt their practices to their local environment. In doing so, they consider cheese as the final expression of their production choices and a way to convey their ethical values.

In continuity with previous works [4,11], our stance for change in values and networks regards more generally every primary commodity integrated into a complex local food system. Those might represent potential seeds of change [4]. However, they are currently minor, and, in our cases, no "civic" initiatives have been observed in Corsica. It raises other questions: Would the configuration leading to sustainable practices be the same? Would targeted sustainable local practices be similar? This is a call for further investigation, from complementary lenses, animal sciences, and a farming systems approach among others, in order to develop a better understanding of such territorial levers for sustainability.

\section{Conclusions}

Beyond labels such as GIs or organic production and commercial brands-so many ways to identify promises to markets and societies for a more sustainable path-sustainability transformations are a chance for controversy. Therefore, they are not spontaneous or easy to enhance. In our paper, we identified a possible lever for change. We emphasized the importance of studying relationships between processors and farmers as they reveal the link between a change of practices and value sharing inside firms. Taking interest in the individual relationships, we understood that environmental sustainability (through choices of sound farming practices) cannot be considered separately from social sustainability (through valuation of milk and recognition of farmers' work).

Figure 1 synthetizes our proposition. It can be understood as a holistic view of the main tensions occurring within localized agrifood systems, influencing sustainable transformations. On one hand, civic and artisan models of relationships (both dairies and farmers providing milk) are dedicating efforts to adapting their practices to their environment. In such dynamics, milk and cheese are oriented together towards a high dependency with the ecosystem. Additionally, the farmers' voice earns more importance in decision making, in a more democratic process assumed by the firms. These models seem to concentrate the seeds of change [4] and might lead the local cheese sector towards sustainable transformations. On the other hand, industrial and merchant models of relationships are more oriented by performance-based polarity. They can be seen as recall forces that hinder sustainability transformations. Innovations promoted in these models are oriented towards intensification and mass production, with top-down efforts for decreasing the level of dependency with terroir. The farmers providing the milk tend to adhere to these values to a certain extent: They consider that, if complying with the set of GI rules, their milk is adapted for mass-market cheeses. Finally, an intermediate model, the paternalistic one, may adopt some traits from one or the other kind of values, playing an ambiguous role in the LAFS dynamics.

More generally, we can notice that such a tension clarifies a common observation: Pathways towards sustainable development are always a compromise between local people expressing various representations of what is to be changed or not. Our work shows that an approach in terms of "worlds of worth" gives a relevant explanation of what is going on when dealing with sustainability transformations within a given supply chain. These transformations need seeds of change and it 
is crucial to identify, among the local actors, who is able to make those seeds emerge, and how they can support associated collective action. Overcoming the question of strict performance or raw material pricing, a values-based approach appears to be a way to enhance sustainable transformation. Sustainability then reveals its deep nature of a strategic project, which needs to be strongly connected to locally shared values on the ecosystem, respect, and solidarity ties for ensuring the involvement of local actors on a long-term perspective.

Author Contributions: All authors elaborated the conceptualization, methodology, and analysis. M.M. and F.C. supervised the Corsican case study and M.M. realized the Pyrenean case study. M.M. prepared the original draft with inputs from F.C.; all reviewed the manuscript.

Funding: This research received no external funding.

Conflicts of Interest: The authors declare no conflict of interest.

\section{References}

1. IPES-Food. The New Science of Sustainable Food Systems. Overcoming Barriers to Food Systems Reform; Report $\mathrm{N}^{\circ} 1$ The Case for a New Science of Sustainable Food System; IPES-Food: Brussels, Belgium, 2015; p. 22.

2. Lamine, C.; Magda, D.; Amiot, M.-J. Crossing Sociological, Ecological, and Nutritional Perspectives on Agrifood Systems Transitions: Towards a Transdisciplinary Territorial Approach. Sustainability 2019, 11, 1284. [CrossRef]

3. Bricas, N.; Lamine, C.; Casabianca, F. Agricultures et alimentations: Des relations à repenser? Nat. Sci. Soc. 2013, 21, 66-70. [CrossRef]

4. Forney, J.; Häberli, I. Introducing 'Seeds of Change' into the Food System? Localisation Strategies in the Swiss Dairy Industry: Introducing seeds of change into the food system? Sociol. Rural. 2016, 56, 135-156. [CrossRef]

5. Alrøe, H.; Sautier, M.; Legun, K.; Whitehead, J.; Noe, E.; Moller, H.; Manhire, J. Performance versus Values in Sustainability Transformation of Food Systems. Sustainability 2017, 9, 332. [CrossRef]

6. Muchnik, J.; Sanz Cañada, J.; Torres Salcido, G. Systèmes agroalimentaires localisés: État des recherches et perspectives. Cah. Agric. 2008, 17, 513-519. [CrossRef]

7. Giacomini, C.; Mancini, M.C. Organisation as a key factor in Localised Agri-Food Systems (LAFS). Bio-Based Appl. Econ. 2015, 4, 17-32.

8. Arfini, F.; Mancini, M.C.; Donati, M. Introduction. In Local Agri-Food Systems in a Global World: Market, Social and Environmental Challenges; Arfini, F., Mancini, M.C., Donati, M., Eds.; Cambridge Scholars Publishing: Newcastle upon Tyne, UK, 2012; pp. 1-8. ISBN 1-4438-3664-8.

9. Bowen, S.; Mutersbaugh, T. Local or localized? Exploring the contributions of Franco-Mediterranean agrifood theory to alternative food research. Agric. Hum. Values 2014, 31, 201-213. [CrossRef]

10. Fonte, M. Knowledge, Food and Place. A Way of Producing, a Way of Knowing. Sociol. Rural. 2008, 48, 200-222. [CrossRef]

11. Bowen, S. Embedding Local Places in Global Spaces: Geographical Indications as a Territorial Development Strategy: Embedding Local Places in Global Spaces. Rural Sociol. 2010, 75, 209-243. [CrossRef]

12. Barham, E. Translating terroir: The global challenge of French AOC labeling. J. Rural Stud. 2003, 19, 127-138. [CrossRef]

13. Vandecandelaere, E.; Teyssier, C.; Barjolle, D.; Jeanneaux, P.; Fournier, S.; Beucherie, O. Strengthening Sustainable Food Systems through Geographical Indications; FAO: Rome, Italy, 2018; p. 158.

14. Vandecandelaere, E.; Arfini, F.; Belletti, G.; Marescotti, A. Linking People, Places and Products: A Guide for Promoting Quality Linked to Geographical Origin and Sustainable Geographical Indications, 2nd ed.; FAO: Rome, Italy, 2010; ISBN 978-92-5-106656-0.

15. Baritaux, V.; Houdart, M.; Boutonnet, J.-P.; Chazoule, C.; Corniaux, C.; Fleury, P.; Lacombe, N.; Napoléone, M.; Tourrand, J.-F. Ecological embeddedness in animal food systems (re-)localisation: A comparative analysis of initiatives in France, Morocco and Senegal. J. Rural Stud. 2016, 43, 13-26. [CrossRef]

16. Tregear, A. Progressing knowledge in alternative and local food networks: Critical reflections and a research agenda. J. Rural Stud. 2011, 27, 419-430. [CrossRef] 
17. Sonnino, R.; Marsden, T. Beyond the divide: Rethinking relationships between alternative and conventional food networks in Europe. J. Econ. Geogr. 2006, 6, 181-199. [CrossRef]

18. Belletti, G.; Marescotti, A.; Touzard, J.-M. Geographical Indications, Public Goods, and Sustainable Development: The Roles of Actors' Strategies and Public Policies. World Dev. 2017, 98, 45-57. [CrossRef]

19. Poméon, T.; Fournier, S. La construction sociale des labels liés à l'origine des produits agroalimentaires: Une conciliation entre des intérêts contradictoires? In Proceedings of the Innovation et Développement Durable Dans L'agriculture et L'agroalimentaire, Montpellier, France, 28 June-1 July 2010.

20. Perito, M.; De Rosa, M.; Bartoli, L.; Chiodo, E.; Martino, G. Heterogeneous Organizational Arrangements in Agrifood Chains: A Governance Value Analysis Perspective on the Sheep and Goat Meat Sector of Italy. Agriculture 2017, 7, 47. [CrossRef]

21. Wezel, A.; Brives, H.; Casagrande, M.; Clément, C.; Dufour, A.; Vandenbroucke, P. Agroecology territories: Places for sustainable agricultural and food systems and biodiversity conservation. Agroecol. Sustain. Food Syst. 2016, 40, 132-144. [CrossRef]

22. Altieri, M. Linking ecologists and traditional farmers in the search for sustainable agriculture. Front. Ecol. Environm. 2004, 2, 35-42. [CrossRef]

23. Belletti, G.; Marescotti, A.; Sanz-Cañada, J.; Vakoufaris, H. Linking protection of geographical indications to the environment: Evidence from the European Union olive-oil sector. Land Use Policy 2015, 48, 94-106. [CrossRef]

24. Tregear, A.; Arfini, F.; Belletti, G.; Marescotti, A. Regional foods and rural development: The role of product qualification. J. Rural Stud. 2007, 23, 12-22. [CrossRef]

25. FAO. SAFA Guidelines: Sustainability Assessment of Food and Agriculture Systems; Food and Agriculture Organization of the United Nations: Rome, Italy, 2014; Version 3.0; ISBN 978-92-5-108485-4.

26. Lamine, C.; Darnhofer, I.; Marsden, T.K. What enables just sustainability transitions in agrifood systems? An exploration of conceptual approaches using international comparative case studies. J. Rural Stud. 2019, 68, 144-146. [CrossRef]

27. Miller, D. The uses of value. Geoforum 2008, 39, 1122-1132. [CrossRef]

28. Barjolle, D.; Jeanneaux, P. Raising Rivals' Costs Strategy and Localised Agro-Food Systems in Europe. Food Syst. Dyn. 2012, 3, 11-21.

29. Mazé, A. Retailers' branding strategies: Contract design, organisational change and learning. J. Chain Netw. Sci. 2002, 2, 33-45. [CrossRef]

30. Dubeuf, B.; Landais, E.; Coulon, J.-B. Problématique de la gestion de la qualité du lait dans la filière fromagère des Alpes du Nord. Etudes et Recherche sur les Systèmes Agraires et le Développement 1994, 28, 115-128.

31. Boltansky, L.; Thévenot, L. On Justifications: The Economies of Worth; Princeton Studies in Cultural Sociology; Princeton University Press: Princeton, NJ, USA, 2006; ISBN 0-691-12516-3.

32. Plumecocq, G.; Debril, T.; Duru, M.; Magrini, M.-B.; Sarthou, J.P.; Therond, O. The plurality of values in sustainable agriculture models: Diverse lock-in and coevolution patterns. Ecol. Soc. 2018, 23, 21. [CrossRef]

33. Champion, F.; Mottet, A.; Morin, E.; Perrot, C.; Dockès, A.-C.; Neumeister, D.; Lagriffoul, G. Bergers Demain en Brebis Laitières. Etude sur la Production Ovine Laitière à L'horizon 2020; Eléments de Diagnostic et Propositions D’actions; Résultats; Institut de L'élevage: Paris, France, 2013; p. 62.

34. Millet, M.; Casabianca, F. Protected Designation of Origin and spatial justice Insights from Ossau-Iraty (French Pyrenees) and Brocciu (Corsica Island). In Proceedings of the 13th European International Farming Systems Association (IFSA) Symposium, Farming Systems: Facing Uncertainties and Enhancing Opportunities, Chania, Greece, 1-5 July 2018; pp. 1-16.

35. Cayre, P.; Michaud, A.; Theau, J.-P.; Rigolot, C. The Coexistence of Multiple Worldviews in Livestock Farming Drives Agroecological Transition. A Case Study in French Protected Designation of Origin (PDO) Cheese Mountain Areas. Sustainability 2018, 10, 1097. [CrossRef]

36. Beaud, S.; Weber, F. Guide de L'enquête de Terrain. Produire et Analyser des Données Éthnographiques; La Découverte: Paris, France, 1998.

37. Millet, M. Hommes, Milieux, Brebis et Laits à la Croisée des Fromages; L'ancrage Territorial des Ovins Laitiers en Corse et en Pyrénées-Atlantiques depuis la fin du XXe Siècle; Université de Corse-Pascal Paoli: Corte, France, 2017. 
38. Casabianca, F.; Millet, M. La ressource génétique locale sous tensions: Trajectoires d'évolution des races ovines laitières Corse et Pyrénéennes, entre modèles d'élevage et valorisation collective des fromages de terroir. Géocarrefour 2018, 3. [CrossRef]

39. Sainte Marie, C.; Mariani, M.; Millet, M.; Cerdan, C.; Casabianca, F. La coexistence entre fromages au lait cru et fromages pasteurisés: Impensable ou impensée? Rev. Agric. Food Environ. Stud.. Submitted.

40. Baritaux, V.; Houdart, M. Relations fournisseurs-grande distribution dans les filières agroalimentaires. Une analyse de la trajectoire d'une démarche «filière qualité». Econ. Rural. 2015, 346, 15-30. [CrossRef]

41. Casabianca, F.; Sylvander, B.; Noël, Y.; Béranger, C.; Coulon, J.-B.; Roncin, F.; Flutet, G.; Giraud, G. Terroir et typicité: Un enjeu de terminologie pour les Indications géographiques. In La Mode du Terroir et les Produits Alimentaires; Les Indes Savantes: Paris, France, 2011; pp. 101-117. ISBN 978-2-84654-278-4.

42. Bérard, L.; Marchenay, P. Localized products in France: Definition, protection and value-adding. Anthropol. Food 2007, S2. Available online: http://journals.openedition.org/aof/415 (accessed on 20 August 2019).

43. Paxson, H. Locating Value in Artisan Cheese: Reverse Engineering Terroir for New-World Landscapes. Am. Anthropol. 2010, 112, 444-457. [CrossRef]

44. Bowen, S. The Importance of Place: Re-territorialising Embeddedness: Embeddedness in the Comté supply chain. Sociol. Rural. 2011, 51, 325-348. [CrossRef]

(C) 2019 by the authors. Licensee MDPI, Basel, Switzerland. This article is an open access article distributed under the terms and conditions of the Creative Commons Attribution (CC BY) license (http://creativecommons.org/licenses/by/4.0/). 